\title{
Action of topical mometasone on the pigmented halos of micrografting in patients with vitiligo*
}

\author{
Ação da mometasona tópica nos halos pigmentares de microenxertia em vitiligo
}

\author{
Karine Dantas Diógenes Saldanha ${ }^{1}$ \\ Francisco Macedo Paschoal ${ }^{3}$
}

\author{
Carlos D`Apparecida Santos Machado Filho²
}

\begin{abstract}
BACKGROUND: Vitiligo is a prevalent skin pigmentation disorder worldwide. The treatments available still offer limited results to some patients. For patients with clinically stable vitiligo, melanocyte transplantation is an appropriate treatment option, and the technique of autologous punch grafting shows good repigmentation.

OвJестіvE: To evaluate the effect of topical mometasone on the halos of repigmentation after autologous punch grafting in patients with clinically stable vitiligo.

MeтноDS: Between 2009 and 2010, 11 patients with clinically stable vitiligo (7 generalized, 2 focal and 2 segmental) underwent autologous punch grafting in the achromic patches. According to the clinical type of vitiligo, patients were instructed to use the corticosteroid ointment during 6 months, only on a few grafted lesions. In the first month, the mometasone ointment was used twice a day and after that just once. They were reassessed 1,3 and 6 months after the procedure. Grafted halos were photographed and recorded using the software fotofinder. After 6 months, all the treated and untreated areas of the repigmentation halos were measured and analyzed comparatively.

RESULTS: The median area of the repigmentation halos after 6 months of treatment with mometasone was larger $\left(25,96 \mathrm{~mm}^{2}\right)$ than the one of the untreated halos $\left(13,86 \mathrm{~mm}^{2}\right)$, showing a statistically significant difference $(p=0,026)$.

Conclusion: In this study, the use of mometasone ointment increased the area of the repigmentation halos after punch grafting. However, this should be further investigated in larger samples in order to validate this positive action in the treatment of stable vitiligo.
\end{abstract}

Keywords: Glucocorticoids; Transplantation; Vitiligo

Resumo: Fundamentos - Vitiligo é um transtorno de pigmentação freqüente na população mundial. Seu tratamento ainda oferece resultados limitados em alguns pacientes. Nos casos de vitiligo estável clinicamente, o transplante de melanócitos tornase uma opção terapêutica, sendo a técnica de enxertos autólogos por punch empregada com boa resposta na repigmentação. OBJETIVOS: Estudar a ação do corticoesteróide tópico mometasona sobre halos de repigmentação após enxertos autólogos por punch em pacientes com vitiligo estável clinicamente.

MÉToDos: Entre 2009 e 2010, 11 pacientes com vitiligo estável (7 do tipo generalizado, 2 focal e 2 segmentar) foram submetidos a enxertos autólogos por punch nas máculas acrômicas. Conforme o tipo clínico do vitiligo, os pacientes eram orientados a aplicar pomada de mometasona por 6 meses em lesões enxertadas selecionadas individualmente. No primeiro mês, a aplicação era 2 vezes ao dia e nos demais, apenas uma vez ao dia. Eram reavaliados nos meses 1, 3 e 6 após enxertos cujos halos eram fotografados e registrados pelo software fotofinder. No fim do 6 mês, todas as áreas dos halos de repigmentação com e sem mometasona foram mensuradas e analisadas comparativamente.

RESULTADOS: A mediana da área dos halos de repigmentação após os 6 meses com mometasona foi superior $\left(25,96 \mathrm{~mm}^{2}\right) \mathrm{com}^{-}$ parada àquela sem mometasona $\left(13,86 \mathrm{~mm}^{2}\right)$, com diferença estatisticamente significante $(\mathrm{p}=0,026)$.

CONCLUSÃo: Em nossa casuística, o uso da mometasona tópica determinou incremento dos halos de repigmentação após enxertia. A amplificação da amostra se faz necessária em estudos posteriores a fim de ratificar esta ação positiva da mometasona no tratamento do vitiligo estável.

Palavras-chave: Glucocorticóides; Transplante; Vitiligo

Received on 28.07.2011

Approved by the Advisory Board and accepted for publication on 23.01.2012

* Work performed at the Faculdade de Medicina do ABC (FMABC) - Santo André (SP), Brazil.

Conflict of interest: I deny any conflict of interest. The objective was the use of mometasone. This laboratory just made the samples available in a bigger quantity, therefore enough for the study.

Financial Support: Mometasone creams (Dermotil) supplied by Glenmark pharmaceutical industry to myself (main author) who would distribute them to all study patients.

Dermatologist - Master in health sciences by the Faculdade de Medicina do ABC (FMABC) - Santo André (SP), Brazil.

Lecturer by the Faculdade de Medicina ABC - Director of the Discipline of Dermatology of the Faculdade de Medicina do ABC (FMABC) - Santo André (SP), Brazil. $\mathrm{PhD}$ in Health Sciences by the Faculdade de Medicina of the Universidade de São Paulo (USP) - Assistant Professor of the Discipline of Dermatology of the Faculdade de Medicina do ABC (FMABC) - Santo André (SP), Brazil. 


\section{INTRODUCTION}

Vitiligo affects approximately $1 \%$ of the population worldwide. It is a pigmentation disorder characterized by achromic patches that, depending on the body region affected, can be classified as localized (focal, segmental) or generalized (totalis, universal). ${ }^{1}$ Also, depending on its clinical activity, vitiligo can be divided into stable and unstable.

Vitiligo results from disrupted epidermal melanization and its etiology has not been defined. ${ }^{2}$ Autotoxic damage or intrinsic changes to the endoplasmic reticulum with melanocyte destruction, pathological changes in fine nerve endings, neuropeptide disturbances and imbalance of humoral and cellular immune response are well documented as participants in the pathogenesis of vitiligo. ${ }^{3}$ However, the sequence of these events leading to depigmentation has not been yet determined.

Because of its unknown etiology, the treatment of vitiligo is still unsatisfactory for some patients, in spite of the advances achieved in recent decades. Several types of treatment, such as UVB phototherapy, UVA associated with oral or topical psoralens and local steroids are commonly used in unstable vitiligo and result in incomplete repigmentation. ${ }^{4}$

Abnormalities of both humoral and cell-mediated immunity have been documented in vitiligo patients and they present a basis for using immunomodulating agents, such as corticosteroids and macrolide immunomodulators such as tacrolimus and pimecrolimus, in the treatment of vitiligo. ${ }^{5,6}$

Topical corticosteroids have been widely used in the treatment of vitiligo, but their use is impractical in generalized vitiligo because of associated adverse effects, such as skin atrophy, telangiectasia, and striae distensae.

In actively spreading vitiligo, systemic corticosteroids can be used to suppress immunity and may arrest the progression of vitiligo and lead to repigmentation. ${ }^{8}$ Complementary therapies have also been used, like oral Zinc, oral L-phenylalanine and others vitamins.

Corticosteroids are a well established treatment of vitiligo and they have been used for a long time. ${ }^{9}$ They are effective in stimulating the repopulation of melanocytes and have anti-inflammatory and immunosuppressive action. ${ }^{10}$

In 1959, Tsukada used corticosteroids intradermally and Bleehen reported that this treatment was effective in repigmentation when used topically. Later, several clinical trials demonstrated the satisfactory effect of corticosteroids, with success rates of $80 \%{ }^{11}$

In a meta-analysis involving randomized controlled trials on the non-surgical treatment of localized and generalized vitiligo, Njoo et al. suggested that class 3 corticosteroids such as betamethasone, mometasone, fluticasone, fluocinolone, and methylprednisolone should be recommended as first-line therapy for patients with localized disease. ${ }^{12}$

From all class 3 corticosteroids, mometasone is a non fluorinated topical one with safety profile and effective in all areas of the human body, mainly in the head, because of its higher melanocyte density. ${ }^{13}$

Many vitiligo patients respond to standard therapeutic options. However, some patients remain recalcitrant, or only improve partially. There are many treatment possibilities for vitiligo, resulting in varying degrees of success. Some attempts are unsuccessful and sometimes frustrating, indicating the absence of melanocyte reserve in the achromic areas. ${ }^{14}$ Treatments are most commonly focused on stopping progression or achieving repigmentation through clinical or surgical methods. ${ }^{15}$

The first reports about the use of surgery in leukoderma date back to the 19th century when Baronio demonstrated good results with experimental skin grafts in sheep. In 1941, Lewin and Peck performed grafts in pigs with good results. In 1972, Norman Orentriech was the first to report repigmentation with autografts in humans. ${ }^{16}$ In 1983, Falabella innovated with the use of $1.5 \mathrm{~mm}$ punches for repigmentation of three cases of segmental vitiligo. Later, this same author reported several cases of successful repigmentation of chemical leukoderma or post-dermabrasion and focal and segmental vitiligo. ${ }^{17}$

The surgical treatments have greatly evolved in the past four decades and brought hope to patients with clinically stable vitiligo. ${ }^{18}$ All of them are based on the same basic principle: autologous transplantation of melanocytes from a pigmented donor area to a receiving achromic area. ${ }^{19}$ Currently, there are several surgical techniques for graft collection: using suction bubble, thin skin fragments, punches, simple curettage, expanded epidermal grafts, in vitro culture, among others. ${ }^{20}$ Among all of these methods, punch grafting is the one most often used as it is easy and quick to perform. Additionally, it is less aggressive and less expensive. ${ }^{21}$

Surgery candidates must have clinically stable vitiligo for at least 1 year, be resistant to other treatments, do not have koebnerization, do not use immunosuppressants, do not have a history of unsightly scars, and not be pregnant. ${ }^{22}$

The objective of the present study was to assess whether mometasone enhances repigmentation of grafts performed in patients with clinically stable vitiligo.

\section{PATIENTS AND METHODS}

We conducted an open non randomized paired controlled clinical trial with an intentional sample, which was obtained from a group of patients treated 
at the outpatient clinic of vitiligo, Skin Institute, Faculdade de Medicina do ABC. The patients included in the study must have had clinically stable vitiligo for at least 1 year (a less frequent condition in this disease). The inclusion criteria were: have been previously treated clinically and showing no satisfactory improvement and being over 12 years (Chart 1). The exclusion criteria were: use of immunosuppressants, unsightly scars or achromic patches in the sacral region (donor area chosen not to be exposed). The study was approved by the Research Ethics Committee of the Faculdade de Medicina do ABC on September 2, 2009.

The stability of the disease was clinically established and defined as either absence of new lesions or lesions with progressive depigmentation, as well as absence of koebnerization, characterized by the appearance of vitiligo lesions induced by physical trauma to the healthy skin. The patients underwent the minigrafting test to confirm this stability. The test consists of collecting two 3-mm fragments of healthy skin using punch from the donor area (sacral region). These fragments were placed in saline solution. Next, a 2-mm skin fragment was collected using punch from each of the two achromic patches (recipient areas), which were selected in advance to receive the graft. After placing these fragments, such recipient areas were occluded with medical tape. Seven days later, the patients returned for a follow-up visit to have the tape removed and to receive counseling. After two months, the patients were reassessed to confirm the absence of koebnerization in the donor and recipient areas, as well as to check for the presence of repig- mentation in the recipient area (pigmented halo approximately 1 to $2 \mathrm{~mm}$ around the graft). If both these data were confirmed, the patients were selected and invited to participate in the protocol. They were also asked to sign a written consent form.

Only eleven patients agreed to participate in the study and continued until the end of the protocol. They were photographed and underwent a new surgical session with the implantation of new grafts in each patch (the number of grafts depended on the size of the lesion area). Thereafter, the patients were asked to avoid using medications that stimulate pigmentation, like oral corticosteroids, psoralens or others complementary treatments.

The procedure consisted on the following phases: asepsis, antisepsis, and local anesthesia (with xylocaine $2 \%$ ) in the donor area; collection of $3-\mathrm{mm}$ skin fragments using punch from the donor area, which were placed in saline solution at $0.9 \%$. The donor area was sutured for better healing. Next, we conducted asepsis, antisepsis, and local anesthesia of two recipient achromic patches of similar size, from which 2-mm fragments were removed using punch to accommodate the grafts. The fragments of the donor area were degreased and implanted into these holes on the donor patches. The patients received a number of grafts required to partially cover these patches, allowing 1-cm spaces between them. Next, the grafted areas were covered using a semi-permeable dressing (Bioclusive $^{\circledast}$ Johnson and Johnson), which was removed seven days later during a follow-up visit.

During this first visit after the procedure, the dressing was removed and the grafts were examined.

CHART 1: Demographic characteristics and previous treatment of each patient before the study

\begin{tabular}{|c|c|c|c|c|c|c|c|c|c|c|c|c|c|c|}
\hline Patient & Age & Gender & $\begin{array}{l}\text { Type } \\
\text { Vitiligo }\end{array}$ & $\begin{array}{l}\text { Time } \\
\text { disease }\end{array}$ & $\begin{array}{l}\text { Topical } \\
\text { CS }\end{array}$ & $\begin{array}{l}\text { Oral } \\
\text { CS }\end{array}$ & $\begin{array}{l}\text { Topical } \\
\text { Immunom. }\end{array}$ & $\begin{array}{l}\text { Multi } \\
\text { vitamin }\end{array}$ & $\begin{array}{l}\text { Topical } \\
\text { Psoral }\end{array}$ & PUVA & UVB & Laser & Cryo & $\begin{array}{l}\text { Sun } \\
\text { Light }\end{array}$ \\
\hline 1. & 37 & $\mathrm{~F}$ & $G$ & 30 & + & - & - & + & - & - & - & - & - & + \\
\hline 2. & 24 & $\mathrm{~F}$ & $\mathrm{~S}$ & 19 & + & - & - & + & + & - & - & - & - & + \\
\hline 3. & 14 & $\mathrm{~F}$ & $\mathrm{~S}$ & 3 & + & - & - & + & + & - & + & + & - & + \\
\hline 4. & 18 & $\mathrm{~F}$ & $\mathrm{~F}$ & 8 & + & - & + & - & + & + & - & - & + & + \\
\hline 5. & 18 & $\mathbf{M}$ & $G$ & 4 & + & - & - & + & + & + & - & - & - & + \\
\hline 6. & 29 & $\mathrm{~F}$ & $G$ & 5 & + & - & - & + & + & - & + & + & - & + \\
\hline 7. & 78 & M & $\mathrm{G}$ & 23 & + & + & + & + & - & + & - & - & - & + \\
\hline 8. & 70 & $\mathrm{~F}$ & $\mathrm{G}$ & 15 & + & - & - & + & + & - & - & - & - & + \\
\hline 9. & 22 & M & $G$ & 7 & - & - & + & + & - & - & - & - & - & + \\
\hline 10. & 55 & $\mathrm{~F}$ & $\mathrm{~F}$ & 3 & + & + & + & + & + & + & + & - & - & + \\
\hline 11. & 49 & $\mathrm{~F}$ & $\mathrm{G}$ & 7 & + & - & + & + & + & - & + & + & - & + \\
\hline
\end{tabular}

- Age and time of disease in years

- Gender = F: Female; M: Male

- Type of Vitiligo = G: Generalized; S: Segmental; F: Focal

- $\mathrm{CS}=$ Corticosteroid

- Immunom. = Immunomodulator
- Psoral. $=$ Psoralen

- PUVA= Oral Psoralen + UVA

- Cryo. = Cryotherapy

- + means Yes, - means No 
The recipient patches were photographed using a digital camera attached to the software fotofinder, which was used to file the images. All patients were instructed to use mometasone furoate cream $0.1 \%$ (pharmaceutical industry Glenmark, São Paulo, Brazil) twice daily for 30 days, only on the lesion located on the right side of the body for those who had generalized vitiligo or on a chosen area of the lesion for those who had segmental or focal vitiligo.

In the second follow-up visit ( 1 month after the procedure), images of the pigmented halos were recorded using fotofinder and the patients were instructed to use mometasone cream once a day on the selected areas.

The third follow-up visit took place in the 3rd month of treatment. The lesions were photographed once more and the use of the cream once a day was recommended.

The fourth follow-up visit was conducted six months after the grafting. The pigmented halos were photographed for the last time during this visit.

Later, we measured each halo using an application of fotofinder that allowed drawing the outer edge of each halo and calculating the internal area in $\mathrm{mm}^{2}$. Based on such data, we were able to compare the increase of the pigmented halos in each patch with and without the use of mometasone, for each patient.

Six months after the procedure, the patients continued to be followed up and treated at the outpatient clinic of dermatology.

The choice of measures of central tendency and dispersion of the values pertinent to the sample and statistical tests for comparison between them were based on the types of distribution. The distributions were defined as non-parametric by the KolmogorovSmirnov test according to the statistical program SPSS $^{\circledast}$ version 17.0 (SSPS ${ }^{\circledast}$ Inc; Illinois, USA). The values of each continuous variable were organized and described by median and interquartile ranges. Absolute and relative frequencies were used for categorical variables. To compare the median areas of the halos with and without mometasone of each patient (nonparametric dependent samples) the Wilcoxon test was used.

\section{RESULTS}

Of the 11 patients enrolled, 8 were female and 3 were male. Their ages ranged from 14 to 78 years (median: 29, interquartile range: 37 . The disease duration varied from 3 to 30 years (median: 7, interquartile range: 15). As for the clinical type of vitiligo, 7 had generalized vitiligo, 2 had focal vitiligo, and 2 had segmental vitiligo. Of the 11 patients studied, 5 had satellite repigmentation (Table 1).

Figures 1 and 2 show the photographic analysis of the areas of pigmented halos after 6 months of minigrafting to patient 10 `s cheeks.

The median size of the areas of pigmented halos treated with mometasone was $25,96 \mathrm{~mm}^{2}$ (interquartile range: 51,59), which was larger than the median area of the halos that did not receive mometasone $\left(13,86 \mathrm{~mm}^{2}\right.$, interquartile range: 44,94$)$, with statistical significance between them $(\mathrm{p}=0,026)$ (Table 2$)$.

\section{DISCUSSION}

In cases of clinically stable vitiligo, grafting provides good results because it allows repopulation of achromic areas using functional cells derived from normally pigmented areas ${ }^{23}$

In some cases, there is a phenomenon called satellite repigmentation. This event has been poorly studied so far and it occurs after punch grafting. It consists on the appearance of melanin pigmentation in peripheral areas that did not receive grafting. This could be caused by the action of donor keratinocytes that might act as a source of growth factors, which stimulate melanocyte donors to proliferate and migrate to the vitiligo patches or, alternatively, by the action of growth factors spread in the achromic patches and responsible for stimulating "dormant" melanocytes. ${ }^{24}$

Conversely, topical corticosteroids are one of the oldest and most widely used methods to treat vitiligo. Studies have reported that corticosteroids enhance the protective and anti-destructive mechanism of melanocytes, inhibit immune changes, block-

TABLE 1: Characteristics related to the grafts of each patient

\begin{tabular}{|c|c|c|c|c|}
\hline Patient & $\begin{array}{l}\text { Grafted } \\
\text { area }\end{array}$ & $\begin{array}{l}\text { Halo } \\
\text { with } \\
\text { momet. }\end{array}$ & $\begin{array}{l}\text { Halo } \\
\text { without } \\
\text { momet. }\end{array}$ & $\begin{array}{l}\text { Satellite } \\
\text { Repigm. }\end{array}$ \\
\hline 1. & Fists & 12 & 8,19 & No \\
\hline 2. & Right Leg & 17,40 & 18,78 & No \\
\hline 3. & Face & 41,55 & 13,86 & Yes \\
\hline 4. & Feet & 72 & 49,50 & No \\
\hline 5. & Hands & 22,13 & 5,50 & No \\
\hline 6. & Legs & 53 & 23,83 & No \\
\hline \multirow[t]{2}{*}{7.} & Anterior & & & \\
\hline & Chest & 11 & 3,57 & Yes \\
\hline 8. & Fists & 5,33 & 9,19 & Yes \\
\hline 9. & $\begin{array}{l}\text { Right } \\
\text { Leg }\end{array}$ & 78,94 & 89,59 & Yes \\
\hline 10. & Face & 64 & 51 & Yes \\
\hline 11. & Hands & 26 & 7,13 & No \\
\hline
\end{tabular}

\footnotetext{
* Median Areas of the halos measured in $\mathrm{mm}^{2}$

* Momet.: mometasone cream

* Satellite repigm. : satellite repigmentation
} 


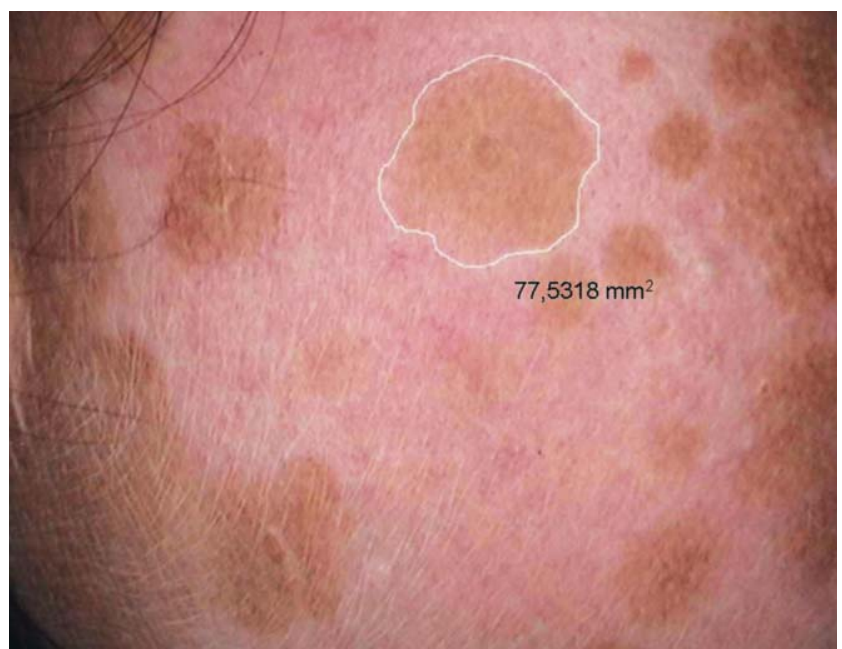

Figure 1: Patient 10: photographic analysis of the right cheek halo that received mometasone after 6 months of micrografting

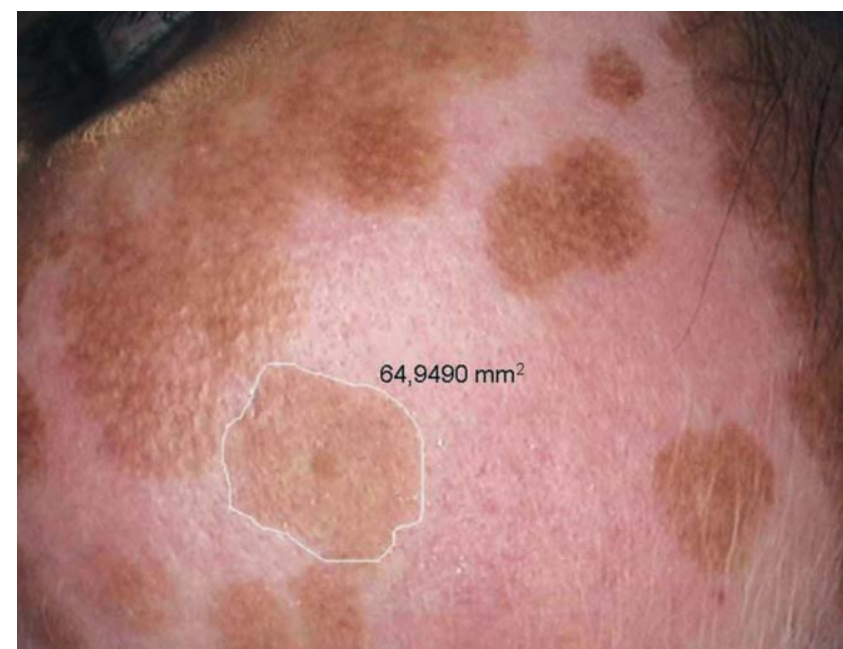

Figure 2: Patient 10: photographic analysis of the left cheek halo that did not receive mometasone after 6 months of micrografting

TABLE 2: Comparison of the median areas of the halos with and without of mometasone

\begin{tabular}{llllll}
\hline & Number & $\begin{array}{l}\text { Minimum } \\
\text { Median }\end{array}$ & $\begin{array}{l}\text { Maximum } \\
\text { Median }\end{array}$ & $\begin{array}{l}\text { Median } \\
\text { of all sample }\end{array}$ & $\begin{array}{l}\text { Interquartile } \\
\text { Range }\end{array}$ \\
\hline $\begin{array}{l}\text { Measurements } \\
\text { with } \\
\text { mometasone }\end{array}$ & 11 & 5,33 & 78,94 & 25,96 & 51,59 \\
$\begin{array}{l}\text { Measurements } \\
\text { without } \\
\text { mometasone }\end{array}$ & 11 & 3,57 & 89,59 & 13,86 & 44,94 \\
\hline
\end{tabular}

$\cdot \mathrm{p}=0,026$

ing T-cells and allowing melanocytes to reactivate. ${ }^{25}$ Class 3 corticosteroids are the most effective and, among them, mometasone was shown to be effective in all parts of the body. Its ability to enhance the protective and anti-destructive mechanism of melanocytes and locally suppress immune changes, enabling melanocytes to repigment, has been demonstrated. Therefore, mometasone is a good therapeutic option to treat vitiligo either alone or in combination. ${ }^{26}$

It is well documented that it is possible to associate surgical methods with other therapeutic modalities, such as laser, heliotherapy, NB-UVB and PUVA therapy, to stimulate melanocyte migration from the follicle and thus promote the occurrence of pigmented halo around the implanted graft. ${ }^{27,28}$

In the present study, which combined autologous punch grafting and use of topical mometasone for 6 months, the statistical analysis using the Wilcoxon test demonstrated that the median areas of the pigmented halos treated with mometasone were larger than those in the areas that were not treated with the corticosteroid, showing a statistically significant difference $(\mathrm{p}=0,026)$.

We found that the largest halos occurred in the patients 9 and 10, who had sun exposure more often, which confirms the importance of light stimulation for repigmentation.

In five out of the 11 patients there was satellite repigmentation. In one patient (number 2), the mean areas of the treated and untreated halos were similar, which may have been caused by the proximity of the grafts. Both findings may be due to the hypothesis of stimulation of donor melanocytes and keratinocytes or action of growth factors on inactive melanocytes.

It is important to highlight that the measure of round halos was more difficult to calculate using fotofinder, as the line drawn on the outer edge of the halos was manually done with the computer mouse, which often makes it difficult to perform short and round movements. Therefore, there might have been 
a measurement bias, which is inherent to all cases, since there was only one observer.

We could not find studies in the literature using the combination of autologous punch grafting and subsequent use of mometasone to evaluate the real impact of this topical corticoid on repigmentation after grafting.

A randomized study was conducted in 2004 by Barman et al evaluating 42 patients divided into two groups. The first group underwent punch grafting and PUVA, and the second group received punch grafting and topical fluocinolone. However, there was no statistically significant difference between the groups. ${ }^{29}$

Conversely, in the present study, we were able to analyze the positive association between mometasone and punch grafting in patients with clinically sta- ble vitiligo, showing a statistical significance, which might serve as a basis for further studies with larger samples.

\section{CONCLUSION}

In spite of the small size of our sample which, from a statistical point of view, is not sufficient to draw definite conclusions, our results suggest a positive impact of mometasone on the progression of pigmented halos.

Further studies with larger samples are needed to reach an accurate conclusion about the true effect of topical mometasone on repigmentation after grafting, which may become a new treatment option for patients with clinically stable vitiligo.

\section{REFERENCES}

1. Barros JA, Machado Filho CDS, Martins LC, Pettinati J, Pinhal MAS. Vitiligo: avaliação histológica e clínica após curetagem seqüencial. An Bras Dermatol. 2007;82:327-35.

2. Nunes DH, Esser LMH. Epidemiological profile of patients with vitiligo and its association with thyroid disease. An Bras Dermatol. 2011;86:241-8.

3. Falabella R, Barona MI. Update on skin repigmentation therapies in vitiligo. Pigment Cell Melanoma Res. 2008;22:42-65.

4. Duarte I, Buense R, Kobata C. Phototherapy. An Bras Dermatol. 2006;81:74-82.

5. Tamler C, Duque-Estrada B, Oliveira PA, Avelleira JCR. Tacrolimus $0,1 \%$ ointment in the treatment of vitiligo: a series of cases. An Bras Dermatol. 2011;86:169-71.

6. Kose 0, Arca E, Kurumlu Z. Mometasone cream versus pimecrolimus cream for the treatment of childhood localizated vitiligo. J Dermatol Treat. 2010;21:133-9.

7. Kostovic K, Pasic A. New treatment modalities for vitiligo: focus on topical immunomodulators. Drugs. 2005;65:447-59.

8. Kim SM, Lee HS, Hann SK. The efficacy of low dose oral corticosteroids in the treatment of vitiligo patients. Int J Dermatol. 1999:38:546-50.

9. Bellet JS, Prose NS. Vitiligo in children: a review of classification, hypothesis of pathogenesis and treatment. An Bras Dermatol. 2005;80:631-7.

10. Gawkrodger DJ, Ormerod AD, Shaw L, Mauri-Solel, Whitton ME, Watts MJ, et al. Guideline for the diagnosis and management of vitiligo. $\mathrm{Br} J$ Dermatol. 2008;159:1051-76.

11. Geraldez CB, Gutierrez GT. A clinical trial of clobetasol propionate in Filipino vitiligo patients. Clin Ther. 1987;9:474-82

12. Njoo MD, Spuls PI, Bos JD, Westerhof W, Bossuyt PMM. Nonsurgical repigmentation therapies in vitiligo. Meta-analysis of literature. Arch Dermatol. 1998;134:1532-40.

13. Masuria BL, Batra A, Kothiwala RK, Khuller R, Singhi MK. Topical mometasone fuorate for the treatment of childhood vitiligo. Indian J Dermatol Venerol Leprol. 1999;65:219-21.

14. Mutalik S, Ginzburg A. Surgical Management of stable vitiligo: A review with personal experience. Dermatol Surg. 2000;26:248-54.

15. Czajkowski R. Comparision of melanocytes transplantation methods for treatment of vitiligo. Dermatol Surg. 2004;30:1400-5.

16. Lahiri K, Sengupta SR. Treatment of stable and recalcitrant depigment skin conditions by autologous punch grafting. Indian J Dermatol Venereol Leprol. 1997;63:11-4.

17. Lahiri K. Evolution and evaluation of autologous mini punch grafting in vitiligo. Indian J Dermatol. 2009;54:159-67.

18. Rusfianti M, Wirohadidjodjo YW. Dermatosurgical techniques for repigmentation of vitiligo. Int J Dermatol. 2006;45:411-7.

19. Parsad D, Gupta S. Standard guidelines of care for vitiligo surgery. Indian J Dermatol. 2008;74 Suppl:S37-45

20. Holla AP, Parsad D. Vitiligo surgery: its evolution as a definite treatment in the stable vitiligo. G Ital Dermatol Venereol. 2010;145:79-88.

21. Khunger N, Kathuria SD, Ramesh V. Tissue grafts in vitiligo surgery past, present, and future. Indian J Dermatol. 2009;54:150-8.

22. Steiner D, Bedin V, Moraes MB, Villas RT, Steiner T. Vitiligo. An Bras Dermatol. 2004:79:335-51.

23. Pianigiani $E$, Andreassi $A$, Andreassi L. Autografts and cultured epidermis in the treatment of vitiligo. Clin Dermatol. 2005;23:424-9.

24. Agarwal US. Satellite repigmentation after punch grafting. Int $J$ Dermatol. 2004;43:273-4.

25. Le Poole C, Boissy R.E. Vitiligo. Semin Cutan Med Surg. 1997;16:3-14.

26. Mahmoud, BH, Hexsel CL, Hamzavi $\mathrm{IH}$. An update on new and emerging options for the treatment of vitiligo. Skin therapy Lett. 2008;13:1-6.

27. Lahiri K, Malakar S, Sarma N, Banerjee U. Repigmentation of vitiligo with punch grafting and narrow band UVB $(311 \mathrm{~nm})$ : a prospective study. Int J Dermatol. 2006; $45: 649-55$

28. Lahiri K, Malakar S, Sarma N, Banerjee U. Inducing repigmentation by regrafting and phototherapy $(311 \mathrm{~nm})$ in punch grafting failure cases of lip vitiligo: a pilot study. Indian J Dermatol Venerol Leprol. 2004;70:156-8.

29. Barman KD, Khaitan BK, Verma KK. A comparative study of punch grafting followed by topical corticosteroid versus punch grafting followed by PUVA therapy in stable vitiligo. Dermatol Surg. 2004;30:49-53.

MAILING ADDRESS:

Karine Dantas Diógenes Saldanha

Av. Dom Luis, 1200 - Sala 1101 Torre I

Bairro Aldeota

60160-230 - Fortaleza -Ceara

Pbone: +55 85 3246-7879

E-mail:kadds@botmail.com

How to cite this article: Saldanha KDD, Machado Filho CDS, Paschoal FM. Action of topical mometasone on the pigmented halos of micrografting in patients with vitiligo. An Bras Dermatol. 2012;87(5):985-90. 